\title{
Nutrition Education 4.0 to Prevent Overweight and Obesity through Social Media
}

Trias Mahmudiono ${ }^{1,2 *} \mathbb{D}$, Su Peng Loh ${ }^{3}$ D, Dominikus Raditya Atmaka ${ }^{1}$ D, Qonita Rachmah ${ }^{1}$ (D), Mahmudah Mahmudah ${ }^{4}$ (D), Shintia Yunita Arini ${ }^{5}$, Mutiara Arsya Vidianinggar ${ }^{1} \mathbb{D}$, Ratih Wirapuspita Wisnuwardani ${ }^{6}$, Kadek Tresna Adhi ${ }^{7}$, Nila Reswari Haryana ${ }^{8}$ D, Setyo Utami Wisnusanti ${ }^{9}$, Windi Indah ${ }^{10}$ iD, Nikmah Utami Dewi ${ }^{11}$ (D)

${ }^{1}$ Department of Nutrition, Faculty of Public Health, Universitas Airlangga, Surabaya, Indonesia; ${ }^{2}$ Center for Health and Nutrition Education, Counseling and Empowerment (CHeNECE), Airlangga, Surabaya, Indonesia; ${ }^{3}$ Department of Epidemiology, Biostatistics and Health Promotion, Faculty of Public Health, Universitas Airlangga, Surabaya, Indonesia; ${ }^{4}$ Department of Occupational Health and Safety, Faculty of Public Health, Universitas Airlangga, Surabaya, Indonesia; ${ }^{5}$ Department of Public Health, Faculty of Public Health, Universitas Mulawarman, Samarinda, Indonesia; ${ }^{6}$ Department of Public Health, Faculty of Medicine, Universitas Udayana, Kuta Selatan, Indonesia; ${ }^{7}$ Department of Nutrition, Faculty of Public Health, Universitas Negeri, Medan, Indonesia; ${ }^{8}$ Department of Nutrition, Faculty of Medicine, Public Health and Nursing, Universitas Gadjah Mada, Yogyakarta, Indonesia; ${ }^{9}$ Department of Nutrition, Faculty of Public Health, Universitas Sriwijaya, Palembang, Indonesia; ${ }^{10}$ Department of Nutrition, Faculty of Public Health, Universitas Tadulako, Palu, Indonesia

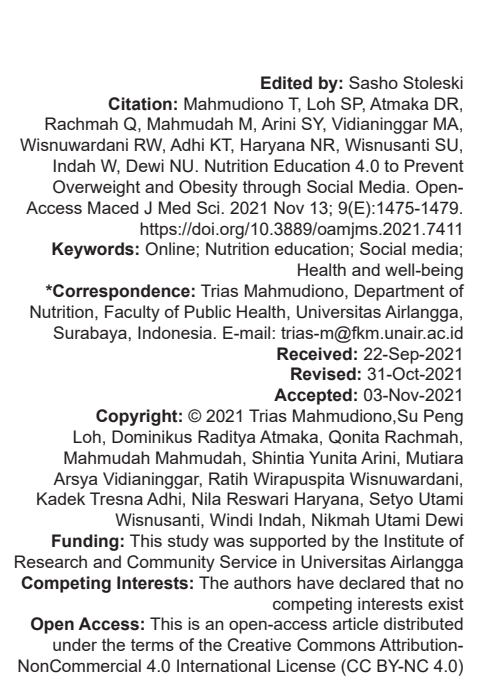

\section{Abstract}

INTRODUCTION: This study was aimed explore the effectiveness of 2 months online-based nutrition education related to reduction of obesity and the risk factor of overweight in adulthood aged 17-25 years compared to the control group. The nutrition education was followed by 800 participants who consist of intervention and control group. The intervention group was given pre-test and post-test each module, on the other hand, control groups only had to join webinar nutrition education.

MATERIALS AND METHOD: Eight hundred early adulthood participants coming from various regions in Indonesia were invited to join WhatsApp group to get intervention by modules and webinar in different topic about nutrition. This is a randomized control trial study by giving nutrition education modules to adults. This study targets adult aged 17-25 years using a quasi-experiment design with a pre- and post-test control group design. The study will be conducted online in eight urban areas (center) in Indonesia, namely: Surabaya, Yogyakarta, Jember, Medan, Bali, Samarinda, Kupang, and Palu City.

\section{Introduction}

\section{Background}

The total number of active social media users in Indonesia in 2020 is 160 million users and 99\% of them access social media through mobile phones. The average use of social media in a day is $3 \mathrm{~h} 26 \mathrm{~min}$. The most widely used social media platforms in Indonesia in 2020 are YouTube, WhatsApp, Facebook, Instagram, and Twitter. Based on profiles of viewer ads from the platforms Facebook, Instagram, and FB Messenger, $30.3 \%$ came from the 18 to 24 year age group and $35.4 \%$ came from the 25 to 24 year age group [1], [2].
About $87.3 \%$ of users aged $17-24$ years use online food delivery applications. In the 17-24 year age group, $30.7 \%$ used online delivery applications 1 time a month, $42.5 \%$ used 1 time every $1-2$ weeks, and $26.7 \%$ used more than 1 time/week. About $75.1 \%$ use the food delivery feature from Gojek and $16.9 \%$ use the Grab application [3].

Obesity is one of the nutritional problems that are increasing from year to year in Indonesia. The prevalence of obesity in Indonesia according to Riskesdas 2018 shows that $13.6 \%$ of adults aged $>18$ years are overweight while $21.8 \%$ are obese [4]. Several comorbidities associated with overweight and obesity includes cancer, type 2 diabetes mellitus, hypertension, stroke, coronary heart disease, and 
other non-communicable diseases [1], [5]. Therefore, it is necessary to intervene to overcome the problem of obesity so that it does not become a problem and a burden on the country's health in the future.

Young adulthood is a stage where there is a life transition from adolescence, increasing independence, increasing autonomy in food choices, physical activity, and the development of cooking skills. One of the challenges in this phase of life is how to influence and encourage young adults to adopt healthy eating behaviors [3], [6]. The high use of social media platforms allows young adults to get a lot of information about nutrition and health from social media [7]. Therefore, one way that can be done to increase knowledge, attitudes, and behavior toward eating habits is to provide nutrition education through social media.

The purpose of this research is to increase knowledge, attitudes, and behavior toward the habit of ordering food online, nutrient-dense food and energydense food, food safety, physical activity, sugarsweetened beverage, as well as intake of energy, protein, fat, and fiber through social media platforms that are widely used by the target.

This research roadmap is in line with the pillars of public health, namely, health promotion (Health Promotion) and public health nutrition (Public Health Nutrition) to improve public health status. The development of research on public health nutrition is directed at the healthy-risk-problem range of nutrition. The form of nutritional problems in this study is over nutrition which consists of overweight and obesity problems. The main focus in research on over nutrition is how to make adolescents and young adults know, want, and be able to improve their own health status and prevent overweight and obesity. Providing education through a platform that is close to adolescents and young adults is expected to increase knowledge, attitudes, and behavior in preventing overweight and obesity.

\section{Study objective}

The aims of the study are to determine the effectiveness of 2 months (three meetings) onlinebased nutrition education related to reduction of obesity and the risk factor of overweight in adulthood aged 17-25 years compared to the control group.

The primary objective is to determine the effectiveness of 2 months (three meetings) onlinebased nutrition education related to reduction of obesity and the risk factor of overweight versus control group on adults' nutritional knowledge.

\section{Primary hypothesis}

Online-based nutrition education for 2 months associated with the food preference to reduction of obesity in adults compared to the control group.

\section{Secondary objective}

Adults' nutrition knowledge and health well-being

1. Determine adults' nutrition knowledge related to reduction of obesity and the risk factor of overweight compared to control group during 2 months (three meetings) of education

2. Determine adults' attitude toward food preference on ordering food online, nutrientdense food and energy-dense food, food security, physical activity, sugar-sweetened beverage, also energy intake, protein, fat, and fiber during 2 months (three meetings) of education

3. Determine the physical activity and intake changes on adults during the COVID-19 pandemic.

\section{Adult's knowledge changes}

1. Measure mean delta change (total change of pre-test and post-test), comparing both intervention groups separately to control group, measured before and after education

2. Determine adults' food preference through pretest and post-test, comparing both intervention and control groups, before and after education

\section{Methods}

\section{Study design}

This research was conducted using a quasiexperimental research design with a pre-test and posttest control group design approach. The use of this experimental design was carried out to measure the effectiveness of providing an intervention in the form of nutrition education to the respondents to be observed. Respondents will be divided into two groups, namely, the group that received the intervention (treatment) and the group that did not receive the intervention (control). The intervention group will be given education through social media while the non-intervention group will be given an educational soft file in the form of a pdf.

\section{Participant selection and enrollment}

Subject is part of the number and characteristics possessed by a population. Subjects are part of the population whose number can be determined using certain methods and existing considerations. One way to calculate the number of subjects is to use Slovin's (1960) formula, as follows:

$$
\mathrm{n}=\frac{N}{1+N e^{2}}
$$




$$
\begin{gathered}
n=\frac{3902}{1+\left[3902 \times\left(0,1^{2}\right)\right.} \\
n=\frac{3902}{1+3902 \times(0,001)} \\
n=\frac{3902}{4,902}
\end{gathered}
$$

$\mathrm{n}=796 \approx 800$ people

It can be seen that:

$\mathrm{n}=$ Number of samples

$\mathrm{N}=$ Total population

$\mathrm{e}=$ Fault tolerance limit $=0.01$

Based on the results of calculations using the Slovin formula, for this study, the results of the calculation of a minimum sample of 100 students for each PTN/PTS student include Airlangga University, Jember University, Gadjah Mada University, Udayana University, Mulawarman University, Medan State University, Tadulako University, and Kupang Health Polytechnic. Total research sample $=800$ students.

\section{Consenting participant}

The participants will be informed about the purpose of the study, the procedures involved when participating, and asked for their consent. Informed consent will be in Indonesian and it also explains briefly about the study, purpose, duration, as well as rights and obligations of respondents. It will be explained to the participants that participation is voluntary and the respondent will be educated particularly by Modules Nutrition Education from the researcher. Participants will receive informed consent through online survey application.

\section{Recruitment of participants}

Due to the COVID-19 pandemic situation, offline recruitment is not possible, so it must be carried out online. The research team conducted several promotions with social media and contacted university directly in eight cities.

\section{Randomization}

Determination of the sample will be done by simple random sampling. This technique is used by sampling where all individuals in the population have the opportunity to be selected as sample members. In this study, the names of students who become the population will be collected, then simple random sampling is carried out by drawing lots to determine the names that will be the treatment group and control group.

\section{Study site}

\section{Setting and number of participant}

The study will be conducted online through modules nutrition education which shared on WhatsApp group in eight urban areas (center) in Indonesia, namely: Surabaya, Yogyakarta, Bali, Palu, Medan, Jember, Kupang, and Samarinda City. We will conduct a "Nutrition Education 4.0 to Prevent Overweight and Obesity Through Social Media" in these eight cities as a means to recruit adults to participate in this study. A total of 800 adults aged $17-25$ years are joining in this research.

\section{Inclusion criteria}

Adults will be included if they meet all the following inclusion criteria:
1. 17-25 years of age
2. Adults majoring health education
3. Intending to follow the nutrition education of the 2 months follow-up
4. Have smartphone and social media.

\section{Exclusion criteria}

Adults were not experiencing metabolic disorder, eating disorder, and recovering from illness will not be included in this study.

\section{Data collection and statistical analysis}

Data will be collected through a pre- and posttest questionnaire and given to all participants (both for intervention and control group) online. All available data will be analyzed descriptively. Results will be summarized as frequencies and percentages for nominal data. Bivariate analysis was done using the Chi-square test with a nominal data scale. Results for bivariate analysis will be summarized as $p$-value and cross-tabulation table. Meanwhile, multivariate analysis was performed using logistic regression tests to determine which variable was the most dominant in influencing dependent variables. The results from the multivariate analysis will be summarized as p-value, odds ratio, and 95\%-confidence interval. The normality test was analyzed using the Kolmogorov-Smirnov test. To analyze the effectiveness of online nutrition education, the ANOVA test will be conducted. All the statistical analyses before will be performed using IBM SPSS 25 software.

\section{Intervention}

\section{Intervention allocation}

The number of research samples was then divided into two groups, namely, the intervention 
group (treatment) and the group that did not receive receive nutrition education materials about the habit of ordering food online, nutrient-dense food and energy-dense food, food safety, physical activity, sugar-sweetened beverage, and intake of energy, protein, fat, and fiber. The treatment group will receive education through social media for 3 months in the form of videos and pictures, while the control group will receive education through books in pdf format. The independent variable in this study was nutrition education. The dependent variable in this study is the subject's characteristics, knowledge, attitudes, and behavior of the subject toward the habit of ordering food online, nutrient-dense food and energy-dense food, food safety, physical activity, sugar-sweetened beverage, and intake of energy, protein, fat, and fiber.

\section{Intervention group}

In the intervention group, participants will get the nutrition education materials from Modules with different topics each week and webinar related nutrition. Baseline and endline for the control group will be conducted in weeks $0-3$. The curriculum for the intervention group is stated in Table 1.

Table 1: Topics Intervention of Nutrition Education

\begin{tabular}{ll}
\hline Weeks & Topics \\
\hline 1 & My Plate \\
2 & Physical Activity \\
3 & Breakfast \\
4 & Fluid Intake \\
5 & Traffic Light Diet \\
6 & Sugar, Salt, and Fat Intake \\
7 & Manifestation of Foods High to Low in Sugar, Salt, and Fat \\
8 & Food Label \\
9 & Popular Diet \\
10 & Low Carb Diet \\
11 & High Fat Diet \\
12 & Calorie Restriction Diet \\
13 & Healthy Diet \\
\hline
\end{tabular}

\section{Control group}

In the control group, participants will get webinar nutrition education. Baseline and endline for the control group will be conducted in weeks 0-1.

All groups will be given the written material through the Center for Health and Nutrition Education, Counseling and Empowerment Research Group's website and can be accessed from https://chenecefkmunair.com/. intervention (control). All students in this study will

Surabaya, Universitas Jember in Jember, Universitas Gadjah Mada in Yogyakarta, Universitas Udayana in Bali, Universitas Mulawarman in Samarinda, Universitas Negeri Medan in Medan, Universitas Tadulako in Palu, Poltekkes Kupang in Kupang. Each university has the responsibility to recruiting each center's respondent since we have eight different locations for nutrition education.

\section{Study Organization}

\section{Coordination}

A field research coordinator will be dedicated to ongoing supervision and monitoring of study implementation. Data collection will be monitored and evaluated regularly by the statistician. Principle investigator along with the field coordinator will also communicate regularly with the coinvestigator to make sure the implementation is going well.

\section{Staff, training, and supervision}

In this study, the researcher gives the nutrition education modules for adults.

\section{Ethical consideration}

The study will be performed in accordance with ethical principles that have their origin in the World Health Organization-Council for International Organizations of Medical Sciences. This study has already been considered by the Health Research Ethics Committee, Universitas Airlangga, Faculty of Public Health, Surabaya, Indonesia No.21/EA/ KEPK/2021. Participants are recruited through the "Nutrition Education 4.0 to Prevent Overweight and Obesity Through Social Media" and given verbal and written information about this research. Furthermore, participants are given verbal and written informed consent by the researcher to fulfill the requirement. Participants may withdraw from this study anytime without negative consequences.

\section{Acknowledgment}

\section{Feasibility}

\section{Study investigator and their roles}

This study is a collaboration research between eight universities in Indonesia: Universitas Airlangga in
This research protocol is based on the study from the researchers from Universitas Airlangga. The author is thanking to all the participants involved in this study in eight cities (Surabaya, Yogyakarta, Bali, Medan, Samarinda, Jember, Kupang, and Palu). 


\section{References}

1. Djalalinia S, Qorbani M, Peykari N, Kelishadi R. Health impacts of obesity-obesity Canada. Pak J Med Sci. 2015;31(1):239-42. PMid:25878654

2. Sapti M. Sikap terhadap pernikahan pada individu dewasa awal yang mengalami perceraian orang tua. Kemamp Koneksi Mat. 2019;53(9):1689-99.

3. Klassen KM, Douglass CH, Brennan L, Truby H, Lim MS. Social media use for nutrition outcomes in young adults: A mixed-methods systematic review. Int J Behav Nutr Phys Act. 2018;15(1):70. https://doi.org/10.1186/s12966-018-0696-y
PMid:30041699

4. Kementerian Kesehatan RI. Panduan Pelaksanaan Gerakan Nusantara Tekan Angka Obesitas (GENTAS). Jakarta, Indonesia: Kementerian Kesehatan RI; 2017. p. 6-16. Avaialble from: http:// www.P2Ptm.Kemkes.Go.Id/Dokumen-Ptm/Panduan-Gentas.

5. Novian A. Jurnal kesehatan masyarakat andalas. Obesitas Sent Dan Kadar Koles Darah Total. 2013;9(1):37-43.

6. Bansode RS, Hiremath RB. Analysis of the covariance structure of health-related indicators in the elderly at home with a focus on subjective health. Comput Ind Eng. 2018;2:6.

7. Maryati Dewi MA. The effect of nutritional knowledge on feeding practice of mothers having stunting toddler aged 6-24 months. Indones J Hum Nutr. 2016;3(1):74-84. 